investigated in relation to their dependence on active vitamin $D$ and parathyroid hormone.

Measurement of serum alkaline phosphatase isoenzymes provides another useful and non-invasive index with which to monitor metabolic bone disease in patients with chronic renal failure. It seems to be more sensitive than the total alkaline phosphatase value, which can be normal even in patients with symptomatic bone complications. Measuring the fractions may also indicate the development of liver disease, but the full significance of raised levels of serum intestinal alkaline phosphatase is not yet understood.

We are grateful to Dr J Kanis of the Churchill Hospital, Oxford, for his helpful criticisms in the preparation of this paper. We also thank Dr B H B Robinson, the staff and patients of the Renal Unit at East Birmingham Hospital, and Dr H G Sammons for their cooperation, and Mrs C D Squire for her skilled technical help.

Requests for reprints should be addressed to Dr R B Naik, Renal Unit, St Mary's Hospital, Milton Road, Portsmouth.

\section{References}

1 Doyle, F H, British Medical Bulletin, 1972, 28, 220.

2 Kyle, L H, Annual Revue of Medicine, 1969, 20, 259.
${ }^{3}$ Stevens, J, and Thomas, F, Clinica Chimica Acta, 1972, 37, 541.

- Price, C P, and Sammons, H G, Fournal of Clinical Pathology, 1974, 27, 392.

5 Johnson, R D, Ellingboe, K, and Gibbs, P, Clinical Chemistry, 1972, 19, 110.

6 Statland, B E, Nishi, H H, and Young, D S, Clinical Chemistry, 1972, 18, 1468 .

${ }^{7}$ Naik, R B, et al, British Medical fournal, 1976, 2, 78.

${ }^{8}$ Bishop, M C, et al, Proceedings of the European Dialysis and Transplant Association, 1971, 8, 122.

${ }^{9}$ Moorhead, J F, et al, Annals of Clinical Biochemistry, 1975, 12, 126.

10 Sagar, S, Borra, S, and Kaye, M, Nephron, 1971, 8, 270.

11 Simpson, W, et al, British fournal of Radiology, 1976, 49, 105.

12 Ivey, K J, and Clifton, J A, Gastroenterology, 1970, 59, 630.

13 Nielsen, V, Clausen, E, and Ranek, L, Acta Medica Scandinavica, 1975, 197, 229.

14 Matas, A J, et al, Lancet, 1975, 1, 883.

15 De Broe, M E, Bosteels, V, and Wieme, R J, Lancet, 1974, 1, 753.

16 Stépán, J, Pilałová, T, and Votrubová, O, Casopis Lekaru Ceskych, 1974, $113,952$.

17 Walker, A W, Clinica Chimica Acta, 1974, 55, (3), 399.

18 Wolfe, M, Dinwoodie, E A, and Morgan, H G, Clinica Chimica Acta, 1969, 24, 131.

19 Saini, P K, and Done, J, Biochimica et Biophysica Acta, 1972, 258, 147.

${ }^{20}$ Chang, C H, and Moog, F, Biochimica et Biophysica Acta, 1972, 258, 154.

${ }^{21}$ Kowarski, S, and Schachter, D, fournal of Clinical Investigation, 1973, 52, 2765.

22 Birge, S J, and Gilbert, H R, fournal of Clinical Investigation, 1974, 54, 710.

(Accepted 11 March 1977)

\title{
25-Hydroxycholecalciferol absorption in steatorrhoea and postgastrectomy osteomalacia
}

\author{
J M GERTNER, MARGARET LILBURN, MERCEDES DOMENECH
}

British Medical fournal, 1977, 1, 1310-1312

\section{Summary}

Post-absorption levels of 25-hydroxy vitamin D (25-OHD) after oral administration of 25-hydroxycholecalciferol $\left(25-\mathrm{OHD}_{3}\right)$ were measured in 11 subjects. Five had presented with steatorrhoea of various causes while six had post-gastrectomy osteomalacia.

Post-absorption levels of 25-OHD were low in four of the patients with steatorrhoea but normal in five of those with post-gastrectomy osteomalacia. There was a significant inverse correlation between peak postabsorption 25-OHD levels and faecal fat excretion.

All patients with active post-gastrectomy osteomalacia had subnormal baseline plasma 25-OHD levels, which indicates that the condition is due to a deficiency of vitamin D. Only two of the patients with osteomalacia had estimated dietary vitamin $D$ intakes over $1.75 \mu \mathrm{g} /$ day.

These findings suggest that an oral 25-OHD absorption test may be a valuable measure of small intestinal function and that poor dietary vitamin $D$ intake rather

Department of Human Metabolism, University College Hospital Medical School, London WC1

J M GERTNER, MB, MRCP, lecturer (now instructor in paediatrics, Yale University School of Medicine, New Haven, Connecticut 06510, USA) MARGARET LILBURN, dietitian

MERCEDES DOMENECH, MD, research assistant (present address: Catedra de Pediatria y Puericultura, Universidad de Valencia, Valencia, Spain) than impaired absorption of the vitamin may be the major cause of post-gastrectomy osteomalacia.

\section{Introduction}

The availability of a sensitive assay for 25 -hydroxy vitamin D (25-OHD) has allowed workers to assess gastrointestinal absorption of this sterol without having to administer radioactive substances to human subjects. ${ }^{1}$ Under physiological conditions $25-\mathrm{OHD}$ is the major circulating vitamin $\mathrm{D}$ metabolite in man ${ }^{2}$ and other animals. Some animal tissues eaten by man-for example, mammalian liver and muscle-contain more 25-OHD than cholecalciferol (vitamin $\left.\mathrm{D}_{3}\right) .^{3} 25-\mathrm{OHD}$ is closely related to vitamin $\mathrm{D}$ in structure, polarity, and physiochemical behaviour, and it is therefore likely to be absorbed from the gastrointestinal tract in the same way as vitamin D-namely, by inclusion in fat micelles formed with the help of bile salts.

We have explored the usefulness of a 25-OHD absorption test in patients presenting with steatorrhoea and in another group presenting with post-gastrectomy osteomalacia. Our first objective was to discover whether there was any relation between the degree of fat malabsorption and the post-absorption rise in plasma 25-OHD levels after an oral load of 25-OHD. Our second aim was to attempt to assess the relative contributions of malabsorption and inadequate vitamin $\mathrm{D}$ nutrition (dietary and cutaneous) in causing post-gastrectomy osteomalacia by studying $25-\mathrm{OHD}$ absorption in patients with this condition.

\section{Patients and methods}

Details of the five patients who presented with steatorrhoea are given in the table. Only case 7 showed evidence of vitamin $\mathrm{D}$ de- 
Clinical, biochemical, and dietary details of patients studied

\begin{tabular}{|c|c|c|c|c|c|c|c|c|c|c|}
\hline \multirow{3}{*}{$\begin{array}{l}\text { Case } \\
\text { No }\end{array}$} & \multirow{3}{*}{\multicolumn{2}{|c|}{$\begin{array}{l}\text { Age } \\
\text { and } \\
\text { sex }\end{array}$}} & \multirow{3}{*}{ Diagnosis } & \multirow{3}{*}{$\underset{(\mathrm{mmol} / \mathrm{l})}{\text { Calcium }}$} & \multicolumn{4}{|c|}{ Plasma } & \multirow{3}{*}{$\begin{array}{c}\text { Faecal } \\
\text { fat } \\
\text { (g/day) }\end{array}$} & \multirow{3}{*}{$\begin{array}{c}\text { Dietary } \\
\text { vitamin D } \\
\text { intake } \\
(\mu g / \text { day })\end{array}$} \\
\hline & & & & & \multirow{2}{*}{$\begin{array}{l}\text { Phosphate } \\
\text { (mmol/l) }\end{array}$} & \multicolumn{2}{|c|}{ Alkaline phosphatase } & \multirow{2}{*}{$\underset{(\mathrm{nmol} / \mathrm{l})}{25-\mathrm{OHD}}$} & & \\
\hline & & & & & & $\mathbf{K} \mathbf{A}$ units & $\%$ bone & & & \\
\hline $\begin{array}{r}1 \\
2 \\
3 \\
4 \\
5 \\
6 \\
7 \\
8 \\
9 \\
10 \\
11\end{array}$ & $\begin{array}{l}59 \\
72 \\
61 \\
61 \\
62 \\
60 \\
61 \\
66 \\
38 \\
55 \\
55\end{array}$ & $\begin{array}{l}M \\
M \\
F \\
F \\
F \\
F \\
F \\
M \\
F \\
M \\
M\end{array}$ & $\begin{array}{l}\text { Post-gastrectomy osteomalacia } \\
\text { ” \# ”, } \\
\#, ", \\
\text { Post-gastrectomy osteomalacia; autonomous hyperparathyroidism } \\
\text { Blind loop syndrome } \\
\text { Post gastrectomy, no osteomalacia; Paget's disease } \\
\text { Gluten-sensitive enteropathy; autonomous hyperparathyroidism } \\
\text { Pancreatic steatorrhoea } \\
\text { Small intestinal resection }\end{array}$ & $\begin{array}{l}2 \cdot 23 \\
2 \cdot 25 \\
2 \cdot 25 \\
2 \cdot 23 \\
1 \cdot 98 \\
2 \cdot 70 \\
2 \cdot 30 \\
2 \cdot 45 \\
2 \cdot 75 \\
2 \cdot 23 \\
2 \cdot 48\end{array}$ & $\begin{array}{l}0.74 \\
0.65 \\
0.90 \\
0.61 \\
1.29 \\
0.71 \\
1.03 \\
1.23 \\
0.71 \\
1.03 \\
1.26\end{array}$ & $\begin{array}{r}35 \\
23 \\
21 \\
21 \\
22 \\
9 \\
10 \\
40 \\
5 \\
7 \\
8\end{array}$ & $\begin{array}{l}95 \\
50 \\
90 \\
90\end{array}$ & $\begin{array}{r}8 \\
8 \\
8 \\
10 \\
8 \\
28 \\
6 \\
38 \\
40 \\
28 \\
19\end{array}$ & $\begin{array}{r}10 \\
5 \\
5 \\
10 \\
14 \\
7 \\
19 \\
17 \\
43 \\
26\end{array}$ & $\begin{array}{l}3.5 \\
1.0 \\
1.1 \\
2.15 \\
1.55 \\
0.75\end{array}$ \\
\hline
\end{tabular}

Conversion: SI to traditional units-Calcium: $1 \mathrm{mmol} / 1 \approx 4 \mathrm{mg} / 100 \mathrm{ml}$. Phosphate: $1 \mathrm{mmol} / 1 \approx 3 \cdot 1 \mathrm{mg} / 100 \mathrm{ml} .25-0 \mathrm{HD}: 1 \mathrm{nmol} / 1 \approx 0 \cdot 4 \mathrm{ng} / \mathrm{ml}$.

ficiency at the time of the study. One patient (case 8) had a raised alkaline phosphatase concentration due to Paget's disease but no radiological evidence of osteomalacia and a normal baseline 25-OHD level. We also performed investigations, including dietary assessments, in six patients who presented with post-gastrectomy osteomalacia.

Five of the six patients with post-gastrectomy osteomalacia had had the Polya operation. No records are available for the type of operation carried out on the sixth patient. Five of these patients had active osteomalacia at the time of the study. The sixth had been treated for osteomalacia three years earlier and was studied during an admission for autonomous hyperparathyroidism, presumably due to previous longstanding osteomalacia. As there had been no change in her gastroenterological status since her osteomalacia was treated we thought that her inclusion in this study was justified. One of the patients with osteomalacia also had osteogenesis imperfecta and another had mild renal impairment (urea $14 \cdot 1 \mathrm{mmol} / 1(85 \mathrm{mg} / 100 \mathrm{ml})$ ). All the patients with active post-gastrectomy osteomalacia had bone tenderness, muscle weakness, increased plasma alkaline phosphatase concentrations, and plasma 25-OHD concentrations below the lower limit of normal found in winter. In addition three of the five had firm histological or radiological evidence of osteomalacia, or both.

The vitamin $\mathrm{D}$ intake from the normal home diets of these patients was assessed. These data are obviously subject to considerable error, as they depend on the patient's recall, but as so few foods contain appreciable quantities of vitamin D such estimates may at least give some evidence of dietary deficiency.

Plasma calcium, phosphorus, and alkaline phosphatase concentrations were measured by standard laboratory techniques. Plasma calcium values were corrected for plasma specific gravity by the formula of Dent. ${ }^{4}$ Alkaline phosphatase was fractionated by the method of Canapa-Anson and Rowe. ${ }^{5}$ Faecal fat excretion was measured over three- to five-day periods.

25-OHD was assayed by the protein-binding technique of Haddad and Chyu. ${ }^{6}$ In our hands this assay can detect $25-\mathrm{OHD}$ concentrations as low as $6-8 \mathrm{nmol} / 1(2 \cdot 4-3 \cdot 2 \mathrm{ng} / \mathrm{ml})$. The normal range of 25-OHD concentrations in British adults is $18 \mathrm{nmol} / 1(7 \cdot 2 \mathrm{ng} / \mathrm{ml}$ ) (winter minimum) to $105 \mathrm{nmol} / 1(42 \mathrm{ng} / \mathrm{ml}$ ) (summer maximum). These studies were carried out over 18 months and thus included all seasons of the year.

The 25-OHD absorption tests were carried out by administering $10 \mu \mathrm{g} / \mathrm{kg}$ body weight of an oily solution of 25 -hydroxycholecalciferol $\left(25-\mathrm{OHD}_{3}\right)$ in gelatin capsules to patients who had fasted overnight. The earlier studies of Stamp, ${ }^{1}$ using identical methods, showed that 25-OHD absorption is not changed by administering the compound in this manner. To standardise conditions of gastric emptying each patient ate a light breakfast as soon as the capsules had been swallowed. Normal meals were then taken for the rest of the test period.

Blood samples for 25-OHD assay were taken before the load was given and again two, four, eight, and 24 hours afterwards (in case 5 , samples were taken at two, four, and 24 hours).

Student's $t$ test was used to test the significance of the coefficient of regression of faecal fat excretion on peak post-absorption rise of plasma 25-OHD concentration.

\section{Results}

The patients' plasma calcium, phosphorus, alkaline phosphatase, and 25-OHD concentrations as well as the measured faecal fat excre- tion are shown in the table. The table also gives the estimated dietary vitamin $\mathrm{D}$ intake of the patients with post-gastrectomy osteomalacia.

Plasma 25-OHD concentrations after oral ingestion of the administered $25-\mathrm{OHD}_{3}$ are shown in figs 1 and 2 . The dotted lines indicate the $95 \%$ confidence limits obtained when the same test was applied to a group of normal subjects by Stamp. ${ }^{1}$

All five patients with steatorrhoea (fig 1) had curves at or below the lower limit of the normal range, while five of the six patients with

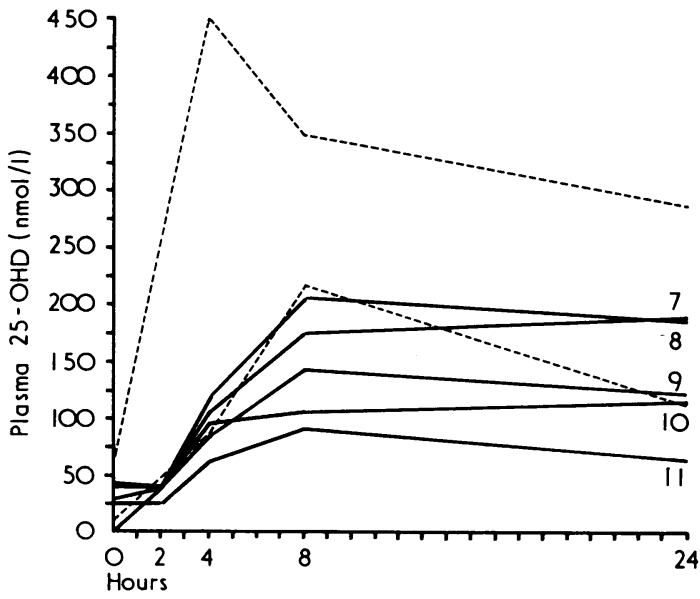

FIG 1-Post-absorption 25-OHD concentrations after ora load of $25-\mathrm{OHD}_{3}, 10 \mu \mathrm{g} / \mathrm{kg}$ body weight, in five patients who presented with steatorrhoea. Load was given at time 0 . Conversion: Sl to traditional units-25-OHD: $1 \mathrm{nmol} / 1$ $\approx 0.4 \mathrm{ng} / \mathrm{ml}$.

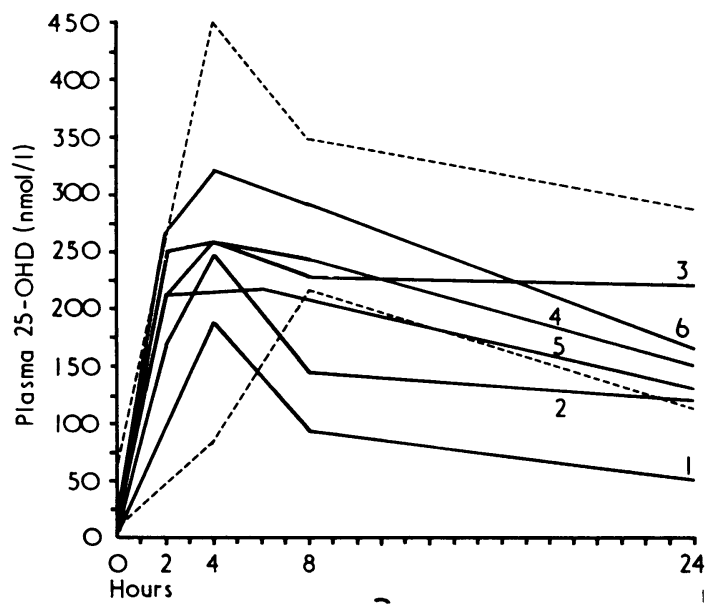

FIG 2-Post-absorption 25-OHD concentrations after oral load of $25-\mathrm{OHD}_{3}, 10 \mu \mathrm{g} / \mathrm{kg}$ body weight, in six patients with post-gastrectomy osteomalacia. Load was given at time 0 . 
osteomalacia had curves largely within the normal range (fig 2). These five patients showed a particularly steep rise in plasma $25-\mathrm{OHD}$ concentrations during the first two hours of the test. No two-hour figure was available in case 1.

Fig 3 shows the relation between faecal fat output and the peak rise in 25-OHD concentration in 10 subjects. There was a significant inverse relation between the two variables $(r=-0.73 ; 0.02>P>0.01)$.

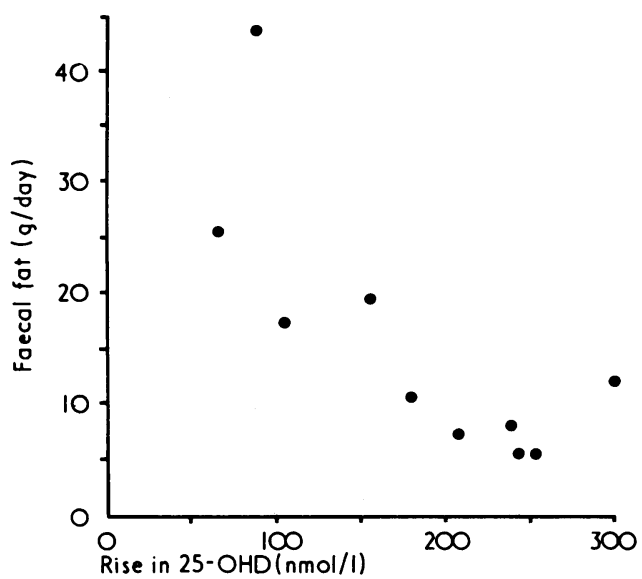

FIG 3-Relation between peak rise in post-absorption 25-OHD concentrations and daily faecal fat excretion. Significant inverse correlation: $r=0.73 ; 0.02>P>$ 0.01

\section{Discussion}

25-OHD is a physiologically important lipid substance that circulates with a biological half time of 13-19 days. " Stamp has shown that plasma levels of the substance increase rapidly after ingestion of an oral load, reaching a peak after four to eight hours and then falling slowly so that the mean 24-hour level is $84 \%$ of the mean peak level. ${ }^{1}$ Our own study has shown that the rate of increase in plasma 25-OHD after an oral load is even faster after gastrectomy, presumably because of more rapid delivery of 25-OHD to the proximal small bowel, known to be the site of maximum vitamin D absorption. Both in this group and in other patients with steatorrhoea, however, we have shown that the peak rise in 25-OHD levels after the load is significantly inversely related to faecal fat output. This permits the $25-\mathrm{OHD}_{3}$ absorption test to be considered as a tool for investigating patients with fat malabsorption.

Post-gastrectomy osteomalacia is a well-recognised complication of certain gastrectomy operations. ${ }^{8-11}$ The subject has been reviewed by Eddy, ${ }^{12}$ who quoted estimates of the incidence of the complication ranging from 1 to $42 \%$. Previous gastrectomy is one of the major causes of osteomalacia presenting in Great Britain. ${ }^{13}$

Some authors have suggested that post-gastrectomy osteomalacia might be due to factors other than simple vitamin D deficiency, in particular to altered intestinal handling of calcium owing to anatomical factors and the presence of steatorrhoea. ${ }^{9}$ This concept, viewing post-gastrectomy osteomalacia as an "end-organ" failure of intestinal response to vitamin $D$, has been largely refuted by subsequent work. Morgan et al ${ }^{14}$ used indirect methods based on the response to treatment to show that this condition was due to vitamin $\mathrm{D}$ deficiency. Thompson et $a^{15}$ reached a similar conclusion using a biological assay of the antirachitic activity of sera from patients with post-gastrectomy osteomalacia. Our study has confirmed that the osteomalacia is indeed due to vitamin $\mathrm{D}$ deficiency by showing that the five patients with active osteomalacia had 25-OHD levels below the lower limits found in a normal population.

Although Thompson et al ${ }^{16}$ showed that patients with post- gastrectomy osteomalacia absorbed radioactive cholecalciferol almost normally there is still considerable doubt about the relative contributions of malabsorption and poor nutrition in causing the condition. ${ }^{12}{ }^{17}$ Most dietary studies of these patients, with the exception of that of Chalmers, ${ }^{13}$ have considered that dietary vitamin $\mathrm{D}$ deficiency is an unlikely major cause of postgastrectomy osteomalacia. Our findings suggest that poor nutrition is the major cause of this osteomalacia. Even though some of the patients had steatorrhoea, $25-\mathrm{OHD}_{3}$ absorption was not seriously impaired. It is, however, possible that the discomfort induced by eating fatty foods leads to a self-chosen vitamin-D-deficient diet. Only two of the patients had estimated vitamin $\mathrm{D}$ intakes above $1.75 \mu \mathrm{g} /$ day. This is the figure below which nutritional vitamin $\mathrm{D}$ deficiency may develop. ${ }^{18}$ Patients who have had gastrectomies may receive less exposure to sunshine than other members of the community, but we could not make any precise estimates of the degree to which this factor might contribute to the development of osteomalacia.

We also considered the possibility that a direct destructive effect of intestinal bacteria on vitamin $D$ or its derivatives may play a part in causing post-gastrectomy osteomalacia. This might have a bearing on the finding that this condition is much commoner in patients who have had Polya gastrectomies than in those who have had other types of gastric surgery. Intestinal bacteria can degrade cholesterol ${ }^{19}$ and bile acids, ${ }^{20}$ which are chemically related to the vitamin D sterols. Recent work has also shown that there is an enterohepatic recirculation of vitamin $\mathrm{D}$ metabolites that might be interrupted in cases of gastrointestinal disease. ${ }^{21}$ Although Thompson $e t$ al ${ }^{16}$ failed to show any destruction of vitamin $D$ by faecal bacteria we think that further work along these lines is needed, and such studies are in progress.

We are grateful to the late Professor C E Dent for encouraging us to carry out this study. Dr Martin Sarner, Professor O M Wrong, Dr D A W Edwards, Dr B D Owen-Smith, and Dr Lyal Watson gave permission to study patients under their care. We also thank Miss Joan Round, Sister Chrys Rayner, and their staff on the University College Hospital metabolic ward and Mrs Josie Wade for her secretarial help. We are indebted to Dr T C B Stamp for his help with preparing the manuscript.

The study was financed with the aid of MRC project grant G974/770/5. The 25-hydroxycholecalciferol was supplied by the Upjohn Co Ltd.

\section{References}

1 Stamp, T C B, Lancet, 1974, 2, 121.

2 Edelstein, S, et al, Clinical Science and Molecular Medicine, 1974, 46, 223.

${ }^{3}$ Fraser, D, personal communication, 1976.

4 Dent, C E, British Medical fournal, 1962, 2, 1419.

5 Canapa-Anson, R, and Rowe, D O F, Fournal of Clinical Pathology, 1970, 23, 400 .

${ }^{6}$ Haddad, J G, and Chyu, K J, Fournal of Clinical Endocrinology and Metabolism, 1971, 33, 992.

${ }^{7}$ Avioli, L V, in Clinical Aspects of Metabolic Bone Disease, ed B Frame, A M Parfitt, and H Duncan, p 355. Amsterdam, Excerpta Medica, 1973.

${ }^{8}$ Baird, I M, and Oleesky, S, Gastroenterology, 1957, 33, 284.

${ }^{9}$ Dellar, D J, and Begley, M D, Australian Annals of Medicine, 1963, 12, 295.

10 Jones, C T, et al, in Partial Gastrectomy, ed F A R Stammers and J A Williams, p 190. London, Butterworth and Co Ltd, 1963.

11 Clark, C G, et al, Lancet, 1964, 1, 734.

12 Eddy, R L, American fournal of Medicine, 1971, 50, 442.

13 Chalmers, J, et al, fournal of Bone and foint Surgery, 1967, 49B, 403.

14 Morgan, D B, et al, Lancet, 1965, 2, 1089.

15 Thompson, G R, et al, Lancet, 1966, 1, 457.

16 Thompson, G R, et al, fournal of Clinical Investigation, 1966, 45, 94.

17 Morgan, D B, et al, Quarterly fournal of Medicine, 1970, 39, 395.

18 Dent, C E, and Smith, R, Quarterly fournal of Medicine, 1968, 38, 195.

19 Eyssen, H, and Parmentier, G, American fournal of Clinical Nutrition, 1975, 27, 1329.

${ }^{20}$ Midtvedt, T, American fournal of Clinical Nutrition, 1975, 27, 1341.

21 Arnaud, S B, et al, Proceedings of the Society for Experimental Biology and Medicine, 1975, 149, 590. 